\title{
Methods for Identifying Patients with Tropomyosin Receptor Kinase (TRK) Fusion Cancer
}

\author{
Derek Wong ${ }^{1} \cdot$ Stephen Yip ${ }^{1} \cdot$ Poul H. Sorensen ${ }^{2,3,4}$ \\ Received: 14 December 2018 / Accepted: 11 June 2019 / Published online: 29 June 2019 \\ (C) Arányi Lajos Foundation 2019
}

\begin{abstract}
NTRK gene fusions affecting the tropomyosin receptor kinase (TRK) protein family have been found to be oncogenic drivers in a broad range of cancers. Small molecule inhibitors targeting TRK activity, such as the recently Food and Drug Administration-approved agent larotrectinib (Vitrakvi®), have shown promising efficacy and safety data in the treatment of patients with TRK fusion cancers. NTRK gene fusions can be detected using several different approaches, including fluorescent in situ hybridization, reverse transcription polymerase chain reaction, immunohistochemistry, next-generation sequencing, and ribonucleic acid-based multiplexed assays. Identifying patients with cancers that harbor NTRK gene fusions will optimize treatment outcomes by providing targeted precision therapy.
\end{abstract}

Keywords NTRK gene fusions · TRK fusions · TRK inhibitors · Next-generation sequencing $\cdot$ NGS

\section{Introduction}

\section{TRK Receptor Family and Signaling}

The tropomyosin receptor kinase (TRK) family is a group of three neurotrophic receptor tyrosine kinase proteins (TRKA, TRKB, and TRKC) encoded by the NTRK1, NTRK2, and NTRK3 genes located on chromosomes 1q23.1, 9q21.33, and 15q25.3, respectively. These receptors are normally expressed in neuronal tissues and have high affinity for and are activated by neurotrophins. Activation of a TRK protein and subsequent signal transduction requires homo-dimerization of TRK membrane receptors following ligand binding [1]. Developmentally, TRK proteins are important for the differentiation and maturation of the central and peripheral nervous system through activation of

Poul H. Sorensen psor@mail.ubc.ca

1 Department of Pathology \& Laboratory Medicine, University of British Columbia, Vancouver, BC, Canada

2 British Columbia Cancer Agency, Provincial Health Services Authority, Vancouver, BC, Canada

3 British Columbia Cancer Research Centre, Vancouver, BC, Canada

4 Department of Pathology, University of British Columbia, 675 West 10th Avenue, Room 4112, Vancouver, BC V5Z 1L3, Canada the phosphoinositide 3-kinase/protein kinase B (PI3K-AKT) and mitogen-activated protein kinase (MAPK) signaling cascades [2-5] (Fig. 1).

\section{NTRK Gene Fusions}

Gene fusions involving the TRK protein family typically involve intra- or inter-chromosomal rearrangements of the $5^{\prime}$ end of a fusion partner containing a dimerization/oligomerization domain with the $3^{\prime}$ region of an NTRK gene encoding the tyrosine kinase domain. The resulting fusion gene leads to the expression of a chimeric protein that lacks the TRK ligandbinding domain but retains the tyrosine kinase domain. This fusion protein harbors oncogenic and transforming potential through overexpression and constitutive activation of the TRK kinase domain due to the presence of a dimerization domain derived from the fusion partner [5-8] (Fig. 2a). Historically, the first NTRK gene fusion was isolated from a human colon carcinoma by classical deoxyribonucleic acid (DNA) transformation assays [10]. The ETV6-NTRK3 gene fusion is the most extensively studied NTRK gene fusion. Recurrent NTRK gene fusions involving ETV6 and NTRK3 (Fig. 2b) were first identified in infantile (or congenital) fibrosarcoma, a malignant tumor of fibroblasts that occur in patients aged 2 years or younger [11], and then shortly after in congenital mesoblastic nephroma, the renal counterpart of infantile fibrosarcoma [12, 13]. Since then, ETV6-NTRK3 fusions have 


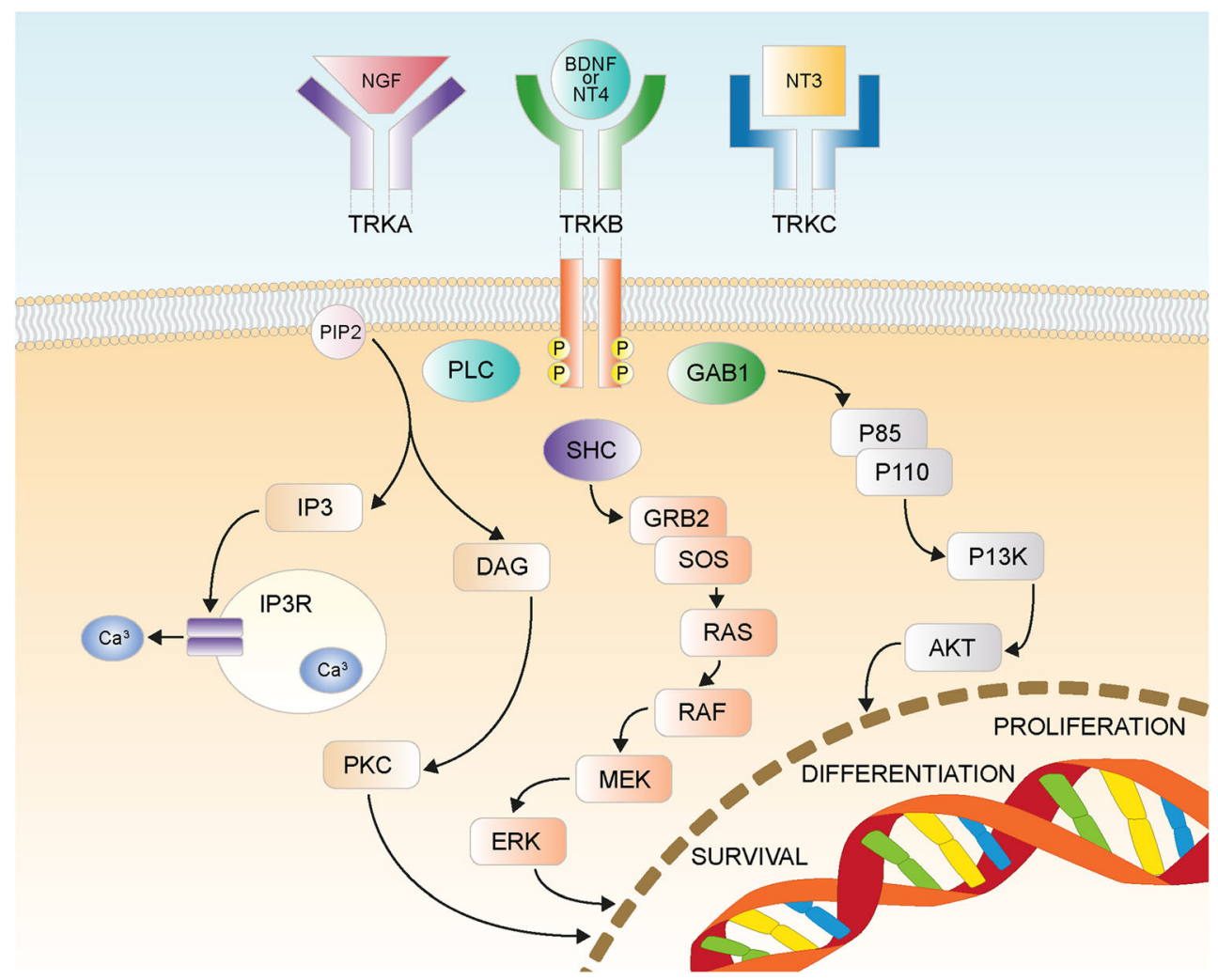

Fig. 1 Tropomyosin receptor kinase (TRK) receptor signaling [5]. AKT, v-akt murine thymoma viral oncogene homolog; BDGF, brain-derived growth factor; DAG, diacylglycerol; ERK, extracellular signal-regulated kinase; GAB1, GRB2-associated-binding protein 1; GRB2, growth factor receptor-bound protein 2; IP3, inositol trisphosphate; MEK, mitogenactivated protein kinase; NGF, nerve growth factor; NTF-3, neurotrophin

been identified in numerous other cancer types, including secretory breast carcinoma [14], acute myeloid leukemia [15], radiation-associated thyroid cancer [16], pediatric high-grade glioma [17], Philadelphia chromosome-like ALL, and other tumor types (Table 1).

Studies investigating the mechanism of ETV6-NTRK3 transformation in NIH $3 \mathrm{~T} 3$ cells and other fibroblasts have revealed that autophosphorylation of this chimeric protein results in the dual activation of RAS-ERK1/2 and PI3K-AKT signaling, and is dependent on homo- and hetero-dimerization mediated by the dimerization domain of ETV6 [7, 50, 51]. Expression of the ETV6-NTRK3 fusion in mammary tissues of mice has also identified early breast progenitor cells rather than stem cells as the direct targets of transformation and has provided valuable models for preclinical studies [52]. Interestingly, the protein encoded by the ETV6-NTRK3 fusion has also been found to interact with and be dependent on the activity of insulin-like growth factor 1 receptor (IGF1R) for both stability and transformation, which may provide another clinical avenue for future treatments [53-55].

Although the ETV6-NTRK3 fusion is the most extensively studied NTRK gene fusion, fusion events involving all three of
3; PI3K, phosphatidylinositol-4,5-bisphosphate 3-kinase; PIP2, phosphatidylinositol 4,5-bisphosphate; PKC, protein kinase C; PLC, phospholipase $\mathrm{C}$; RAF, rapidly accelerated fibrosarcoma kinase; RAS, rat sarcoma kinase; SHC, Src homology 2 domain containing. Reproduced with permission from Amatu A, Sartore-Bianchi A, Siena S. ESMO Open 2016;1(2):e000023

the NTRK genes and over 50 different $5^{\prime}$ fusion partners have been identified (Table 1). NTRK gene fusions have been found in over 20 different cancer types and in up to $1 \%$ of all solid tumor malignancies, suggesting that NTRK gene fusions may be oncogenic drivers regardless of the tumor type [8].

\section{Clinical Data for TRK Inhibitors}

Fusions involving TRK proteins lead to constitutive activation of the kinase domain similarly to many other oncogenic drivers such as $B C R-A B L$ translocation and $E G F R$ amplification/mutation. One strategy in targeting these kinds of oncogenic drivers has been to develop small molecule inhibitors to block the downstream signaling pathways that are activated and drive the cancer. Currently, there are several small molecular inhibitors targeting TRK in phase II clinical trials; the most notable are larotrectinib, a highly selective TRK inhibitor (TRKA/B/C), and entrectinib, a broader tyrosine kinase inhibitor $(T R K A / B / C$, $R O S 1, A L K)[5,56]$. Both have demonstrated the ability to cross the blood-brain barrier, making them suitable agents for central nervous system (CNS) tumors that harbor TRK fusions $[57,58]$. Clinical basket trials using larotrectinib (NCT02122913, 
Fig. $2 N T R K$ gene fusions. (a) Mechanism of NTRK1/2/3 gene fusions; (b) ETV6-NTRK3 gene fusion [9]. DNA,

deoxyribonucleic acid; LBD, ligand-binding domain; PTK, tyrosine kinase; TRK, tropomyosin receptor kinase; TM, transmembrane; SAM, sterile alpha motif. Figure $2 \mathrm{~b}$ reproduced with permission from Triche TJ, Hicks MJ, Sorensen PH. Diagnostic Pathology of Pediatric Malignancies. In: Pizzo PA, Poplack DG, editors. Principles and Practice of Pediatric Oncology, 7th Edition: Wolters Kluwer Health; 2015 a

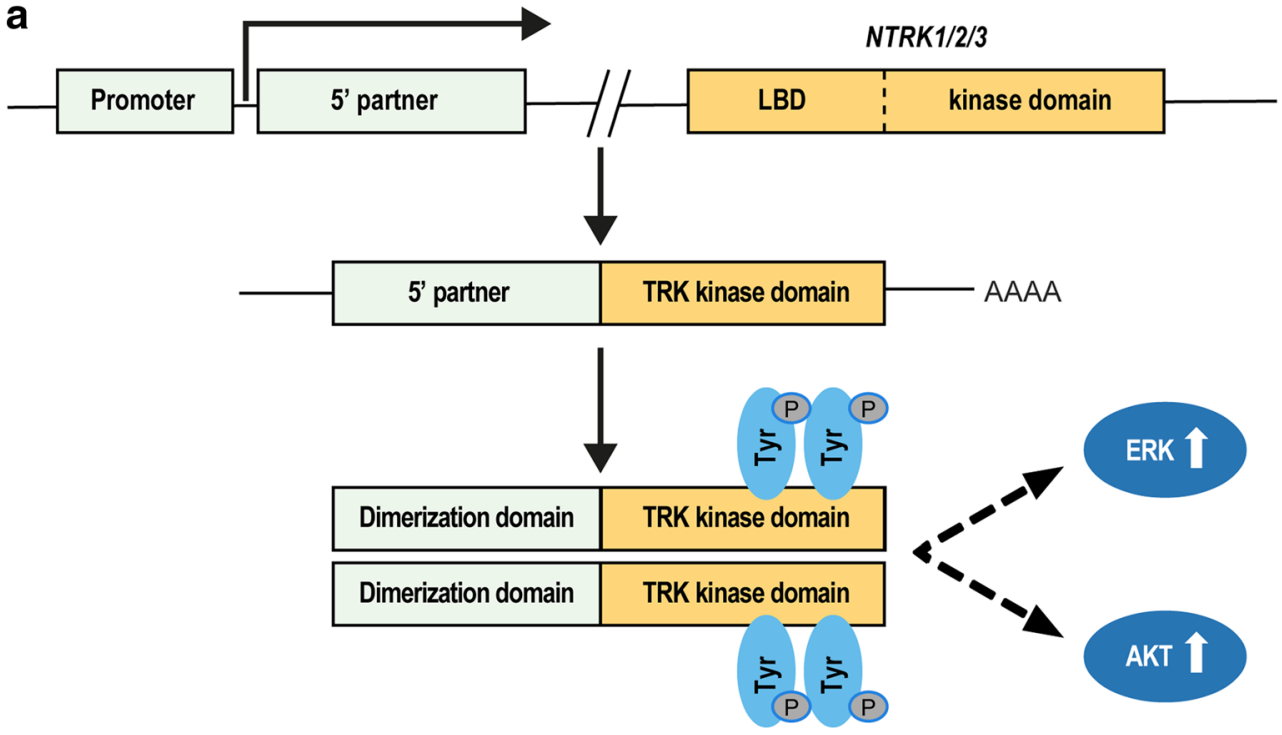

b ETV6

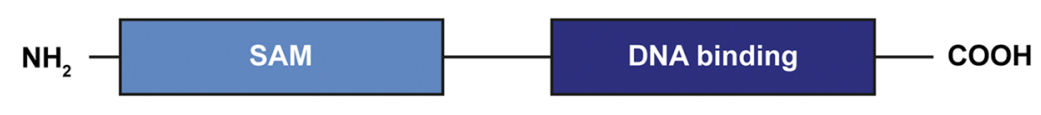

NTRK3

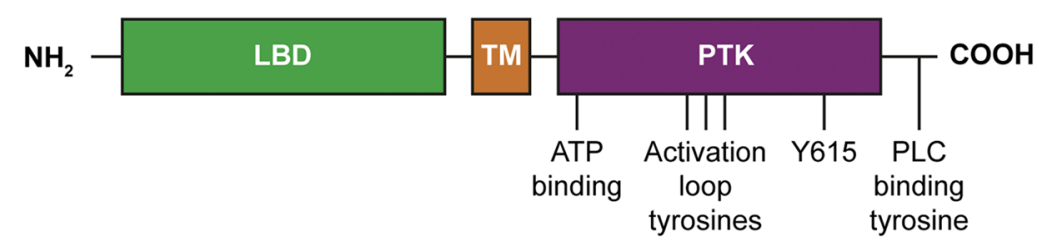

ETV6-NTRK3

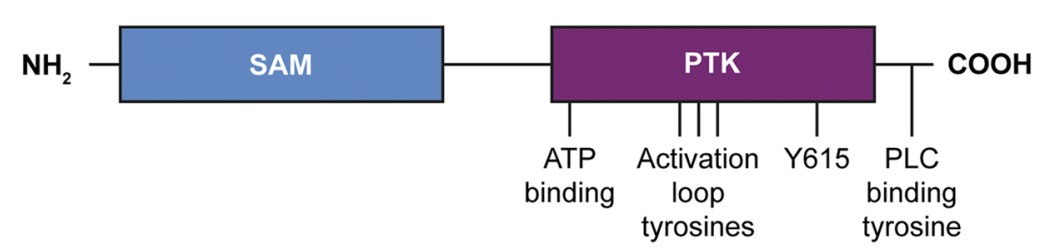

NCT02637687, NCT02576431) have shown durable overall response rates of $93 \%$ in a pediatric phase I/II trial and $75 \%$ in a combined adult and pediatric phase I/II trial $[23,59]$. Adverse events were predominantly grade 1 or grade 2 with no grade 3 or grade 4 adverse events attributable to larotrectinib seen in more than $5 \%$ of the patients regardless of tumor type or fusion partner $[23,59]$. These data clearly demonstrate the potency of larotrectinib as a therapeutic option for patients that harbor NTRK gene fusions. Similarly, phase I/IIa clinical trials for entrectinib demonstrated low toxicity with reversal of sideeffects following dose monitoring [22]. Larotrectinib has been recently approved for use in the United States for patients with solid tumors that harbor an NTRK fusion gene [60]. Clinical trials for both drugs are still currently on-going and further support the utility of identifying TRK fusion cancers in order to provide effective and durable clinical therapeutic options to patients. In this review, we summarize the methods available for detecting NTRK gene fusions in cancer.

\section{Methods to Identify Patients with TRK Fusion Cancer}

Several different approaches have been used to detect the presence of NTRK gene fusions at the DNA and ribonucleic acid (RNA) level and TRK expression. These methods include traditional clinical assays such as fluorescent in situ hybridization (FISH), reverse transcription polymerase chain reaction (RT-PCR), immunohistochemistry (IHC), and newer, emerging technologies such as next-generation sequencing (NGS) and RNA-based multiplexed assays (Nanostring). Each technique is associated with advantages and disadvantages (Table 2). 


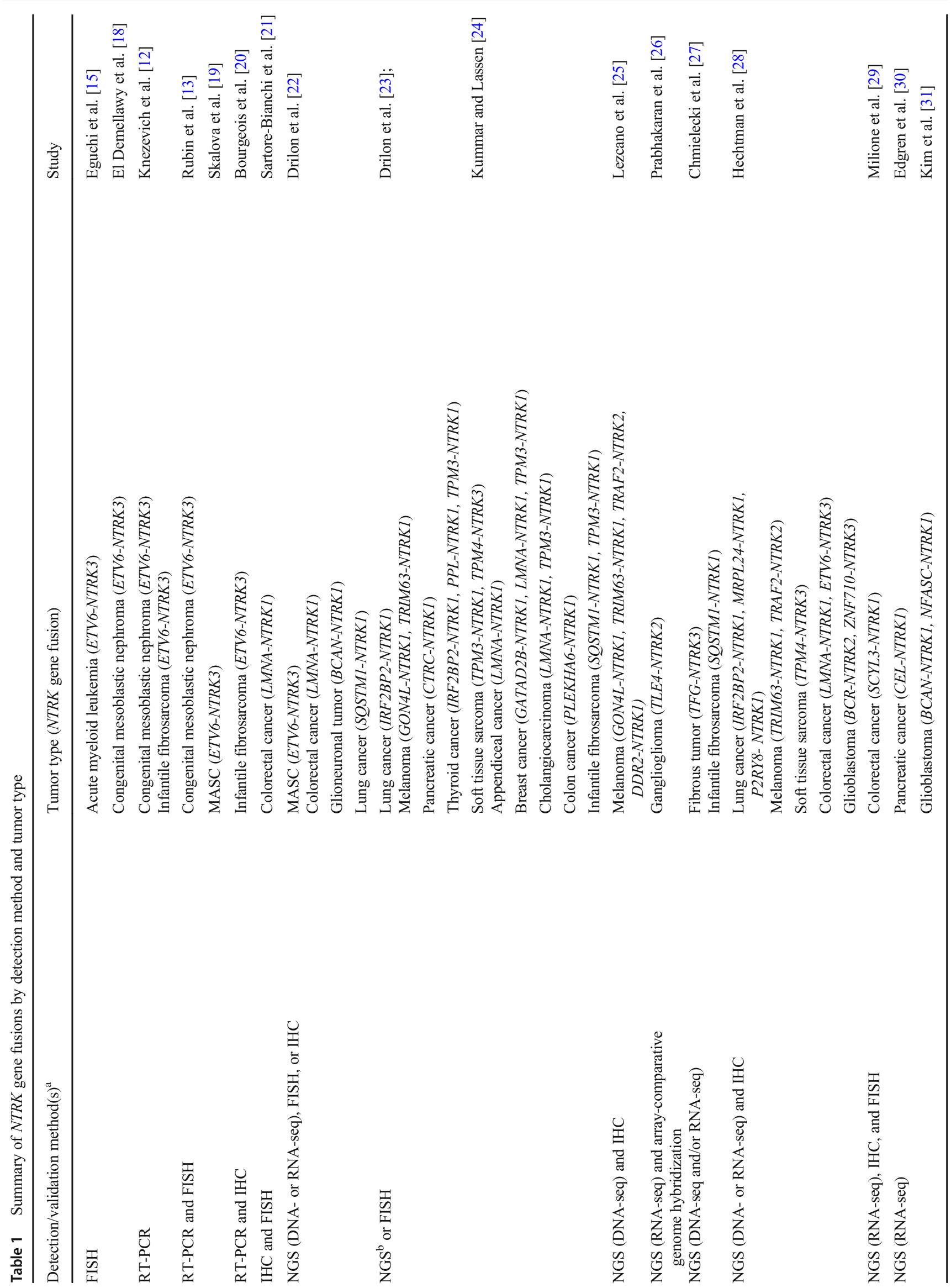




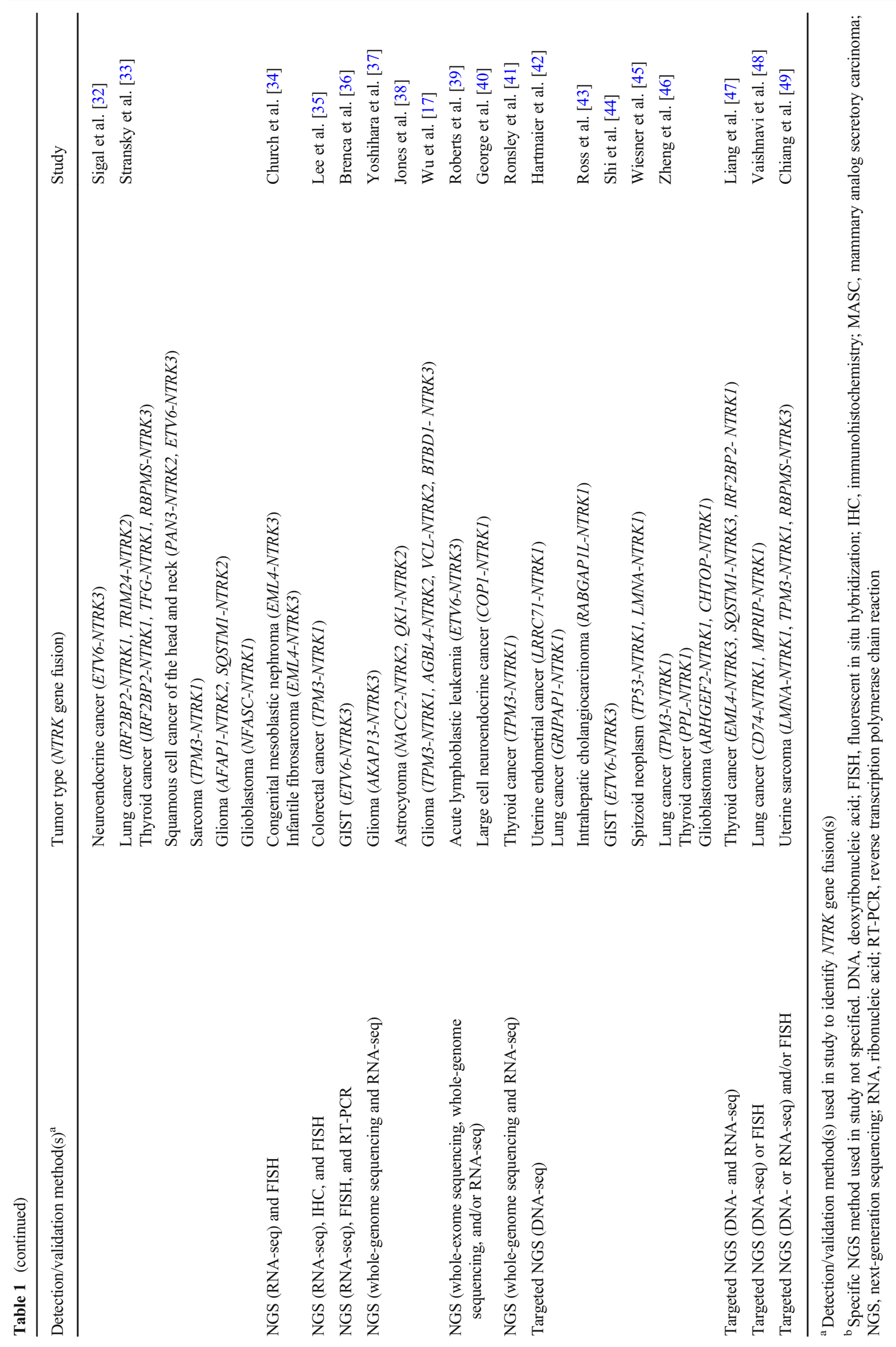


Table 2 Advantages and disadvantages of methodologies for detecting tropomyosin receptor kinase (TRK) fusion cancer

\begin{tabular}{|c|c|c|c|c|}
\hline & $\begin{array}{l}\text { Fluorescence in situ } \\
\text { hybridization (FISH) }\end{array}$ & $\begin{array}{l}\text { Reverse transcription } \\
\text { polymerase chain } \\
\text { reaction (RT-PCR) }\end{array}$ & $\begin{array}{l}\text { Pan-TRK } \\
\text { immunohistochemistry } \\
\text { (IHC) }\end{array}$ & $\begin{array}{l}\text { Next-generation } \\
\text { sequencing (NGS) }\end{array}$ \\
\hline \multirow[t]{5}{*}{ Advantages } & $\begin{array}{l}\text { - Location of the target within the } \\
\text { cell can be detected [61] }\end{array}$ & $\begin{array}{r}\text { - High sensitivity and } \\
\text { specificity }[20,62]\end{array}$ & $\begin{array}{l}\text { - Inexpensive }[63,64] \\
\text { - Decentralized, available } \\
\text { in most laboratories [20] }\end{array}$ & $\begin{array}{l}\text { - Detection of novel fusion } \\
\text { partners [34] and fusions } \\
\text { expressed at RNA level [65] }\end{array}$ \\
\hline & - High sensitivity and specificity [63] & $\begin{array}{l}\text { - Assays detect fusions } \\
\text { expressed at the } \\
\text { RNA level [62] }\end{array}$ & $\begin{array}{l}\text { - Established } \\
\text { reimbursement codes } \\
\text { [66] }\end{array}$ & $\begin{array}{l}\text { - Ability to test multiple } \\
\text { actionable targets } \\
\text { simultaneously [34] }\end{array}$ \\
\hline & $\begin{array}{l}\text { - Several fluorophores can be used } \\
\text { at once to detect different targets } \\
\text { in one sample [67] }\end{array}$ & • Inexpensive [68] & $\begin{array}{l}\text { - Turnaround time: } \\
\sim 2 \text { days [64] }\end{array}$ & $\begin{array}{l}\text { - Plays key role in diagnostic } \\
\text { work-up of TRK fusion can- } \\
\text { cer [23] }\end{array}$ \\
\hline & & & & $\begin{array}{l}\text { - Relevance of NGS increases } \\
\text { as number of actionable } \\
\text { targets grows [69] }\end{array}$ \\
\hline & & & & $\begin{array}{l}\text { - High sensitivity and specificity } \\
\text { potential [63] }\end{array}$ \\
\hline \multirow[t]{5}{*}{ Disadvantages } & - Requires fluorescence microscopy [61] & $\begin{array}{l}\text { - Target sequences must } \\
\text { be known; unable to }\end{array}$ & $\begin{array}{l}\text { - Cannot differentiate } \\
\text { between fusion and }\end{array}$ & $\begin{array}{l}\text { - Turnaround time: } \sim 1-3 \\
\text { weeks [69] }\end{array}$ \\
\hline & & $\begin{array}{l}\text { detect novel fusion } \\
\text { partners }[34,68]\end{array}$ & $\begin{array}{l}\text { wild-type TRK expres- } \\
\text { sion [28] }\end{array}$ & $\begin{array}{l}\text { - Technically complex and } \\
\text { costly [70] }\end{array}$ \\
\hline & $\begin{array}{l}\text { - Target sequence must be known; unable } \\
\text { to detect novel fusion partners unless } \\
\text { break-apart probes are used [34] }\end{array}$ & $\begin{array}{l}\text { - Development of } \\
\text { separate tests required } \\
\text { for each NTRK gene } \\
\text { [71] }\end{array}$ & $\begin{array}{r}\text { - Scoring algorithms are } \\
\text { not standardized [20] }\end{array}$ & $\begin{array}{l}\text { - Requires highly centralized } \\
\text { testing model [34] and } \\
\text { bioinformatics infrastructure } \\
\text { [72] }\end{array}$ \\
\hline & $\begin{array}{l}\text { - Development of separate tests required } \\
\text { for each NTRK gene [71] }\end{array}$ & & $\begin{array}{l}\text { - Additional testing required } \\
\text { to determine course of }\end{array}$ & $\begin{array}{l}\text { - Reimbursement currently } \\
\text { restricted [73] }\end{array}$ \\
\hline & $\begin{array}{l}\text { - Cannot demonstrate that functional } \\
\text { protein has been generated }[34,67]\end{array}$ & & action $[28]$ & $\begin{array}{l}\text { - Sensitivity and specificity } \\
\text { of NGS assays vary widely } \\
{[63,74]}\end{array}$ \\
\hline
\end{tabular}

\section{FISH}

Historically, FISH has been the gold standard for the clinical detection of gene fusions (e.g. $B C R-A B L$ rearrangements in chronic myeloid leukemia) [75]. FISH uses fluorescently labeled RNA or DNA probes that bind to complementary sequences on formalin-fixed paraffin embedded (FFPE) tumor samples. For gene fusions typical of certain malignancies (e.g. ETV6-NTRK3 in infantile fibrosarcoma), dual color FISH probes can be used. One major advantage of FISH analysis is the ability to detect the presence of a fusion event involving a target gene without prior knowledge of the fusion partner by utilizing "breakapart" probes, where each probe is directed to the $5^{\prime}$ and $3^{\prime}$ ends of the target gene, respectively (Fig. 3a and b). An intact NTRK gene would result in overlapping probes and produce yellow fluorescence whereas a translocation event would result in the probes "breaking apart" to produce two individual probes (red and green) indicating a break in the gene most likely arising from a chromosomal translocation. An example is the detection of a LMNA-NTRK1 fusion using break-apart probes in a softtissue sarcoma [76] (Fig. 3c). Although this method is useful when the fusion partner is unknown, individual FISH analysis must be performed for each of the three NTRK genes due to the sequence specificity of the probes; this can be labor- and cost-intensive. Lastly, due to the detection of gene rearrangements at the DNA level, FISH does not provide any information as to whether an oncogenic fusion protein is produced.

\section{RT-PCR}

Tumor RNA from fresh frozen or FFPE samples can be extracted and converted to complementary DNA (cDNA) sequences using reverse transcription. The cDNA is then amplified using polymerase chain reaction (PCR) primers that are located on either side of the fusion breakpoint, resulting in a PCR amplification product only when that specific fusion is present. The amplification products can then be visualized using intercalating dyes that bind to double-stranded DNA or a fluorescent reporter-quencher system that allows for multiplexing of multiple primer sets [77]. RT-PCR provides a highly specific, rapid, economical, and sensitive testing method, even at low transcript levels, with quick turnaround time and multiplexing capabilities [78] compared with FISH analysis. However, RT-PCR requires prior knowledge of the 
Fig. 3 Break-apart fluorescent in situ hybridization (FISH). (a) The wildtype pattern shows two pairs of closely situated or fused signals. (b) In break-apart FISH, a set of probes specific for the target gene is used. When translocation occurs involving a breakpoint between the two probe sites, the loci split apart. (c) An example of break-apart FISH testing results in a patient with soft-tissue sarcoma and an LMNA-NTRK1 gene fusion [76]. NTRK1 break-apart FISH demonstrates both paired green ( $\left.5^{\prime} N T R K 1\right)$ and red ( $3^{\prime}$ NTRK1) signals corresponding to the normal NTRK1 gene (yellow arrow). Isolated red signals (red arrows) are observed in tumor nuclei (stained blue with DAPI) indicative of a chromosomal deletion leading to an NTRK1 gene fusion. DAPI, 4',6-diamidino-2phenylindole. Figures $3 \mathrm{a}$ and $\mathrm{b}$ reproduced with permission from Cheng L, Zhang S, Wang L, MacLennan GT, Davidson DD. J Pathol Clin Res 2017;3(2):73-99. Figure $3 \mathrm{c}$ reproduced with permission from Doebele RC, Davis LE, Vaishnavi A, Le AT, EstradaBernal A, Keysar S, et al. Cancer Discov 2015;5(10):1049-57 a
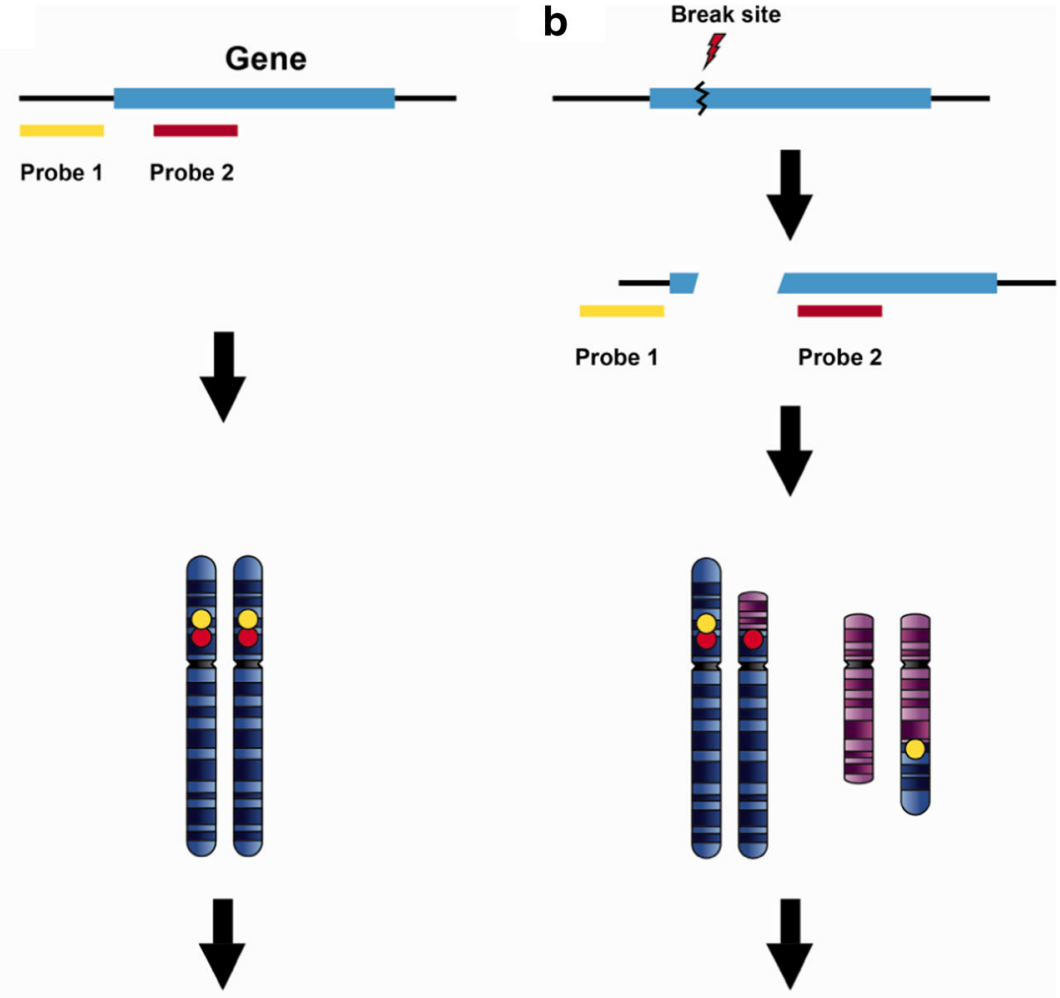

Wild type

Break apart

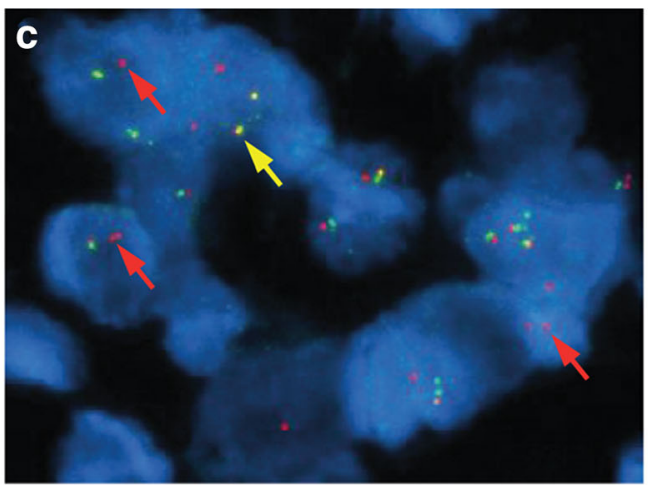

fusion partners. A variation of RT-PCR that can detect the presence of a fusion with an unknown partner has been developed [79]. Although RT-PCR has a quick turnaround time once established, the design and validation of each primer set is labor intensive, more so when multiplexing multiple primer sets, which introduces the potential for cross-interactions. Robust detection by RT-PCR also relies on the quality of the RNA extracted, which can vary greatly due to the unstable nature of RNA. An example of the detection of an ETV6-NTRK3 fusion in a mammary analog secretory carcinoma using RT-PCR is presented in Fig. 4a [80].

\section{IHC}

While FISH and RT-PCR are used to detect fusions at the DNA and RNA level, respectively, IHC can be used to survey the protein expression of your target of interest using antibodies tagged with a colorimetric label. In contrast to FISH, the availability of a pan-TRK antibody eliminates the need to perform individual assays for each TRK protein. The use of a pan-TRK monoclonal antibody has been shown to be sensitive and reliable, identifying TRK expression in 20/21 cases in one study [28] and 21/28 cases in another study [81]. In the second study, pan-TRK IHC was less effective in detecting 


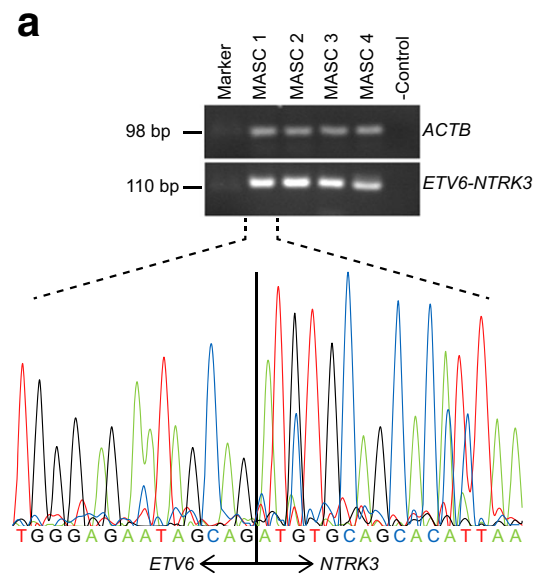

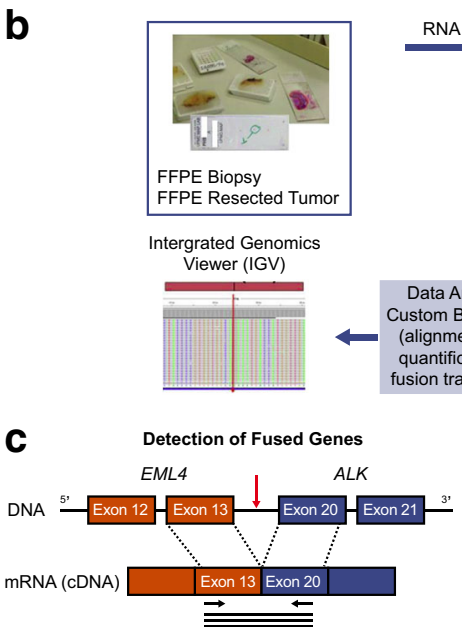

Fig. 4 Reverse transcription polymerase chain reaction (RT-PCR) and next-generation sequencing (NGS). (a) Example results for reverse transcription polymerase chain reaction (RT-PCR) testing [80]. RT-PCR for ETV6-NTRK3 fusion transcripts in mammary analogue secretory carcinoma (MASC) tumors. ACTB, $\beta$-actin, MASC 1, MASC 2, MASC 3 and MASC 4, tumor samples from Case 1, Case 2, Case 3, and Case 4, respectively. (b-d) Summary of NGS [79]. (B) RNA is extracted from formalin-fixed, paraffin-embedded (FFPE) tumor specimens and reverse transcribed into complementary DNA (cDNA). The cDNA is amplified with a panel of primers targeting fusion and native control transcripts. The resulting libraries are sequenced on Ion Torrent instruments and the fusions involving $N T R K 3$, which may reduce the overall sensitivity of IHC as the ETV6-NTRK3 fusions has been reported as the most common TRK fusion in pan-cancer studies [33, 81]. An example of the detection of a protein resulting from the LMNA-NTRK1 fusion using IHC can be found in Fig. 5 [28]. A pan-TRK monoclonal antibody has been recently approved for in vitro diagnostic use (Ventana Medical Systems), which should provide a more reproducible reagent for the detection of TRK expression. One caveat when using IHC to detect TRK is that the antibody does not discriminate between expression of the wildtype and fusion protein. Therefore, strong staining may indicate either expression of the wildtype protein or the presence of a TRK fusion protein. Interpretation

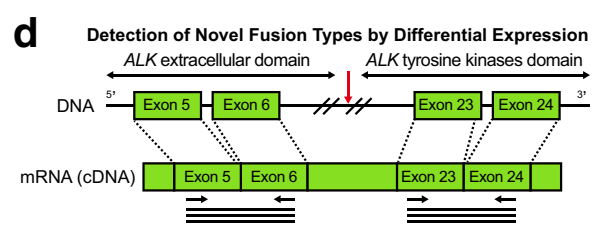

sequence reads are then enumerated using a custom pipeline. Identified fusion transcripts are confirmed in the Integrative Genomics Viewer (IGV) to check that sequence reads span both fusion partners. (C) Fused genes are detected by PCR amplicons that span a known fusion breakpoint. (D) Novel fusions may also be detected based on overexpression of the kinase domain of selected targets. Figure 4 a reproduced with permission from Fehr A, Loning T, Stenman G. Am J Surg Pathol 2011;35(10):1600-2. URL: https://journals.lww.com/ajsp/Citation/2011/ 10000/Mammary_Analogue_Secretory_Carcinoma_of_the.20.aspx. Figures $4 \mathbf{b}-\mathbf{d}$ reproduced with permission from Beadling $\mathrm{C}$, et al. J Mol Diagnostics. 2016;18(2):165-175

of IHC results can also be subjective due to the heterogeneity of normal tissue expression and thus requires strict controls. However, IHC remains a cost- and sample-effective method with quick turnaround times. Moreover, IHC is commonly used and widely available in most pathology laboratories and may be an effective initial screening step for TRK fusions prior to confirmation with a secondary method such as NGS.

\section{NGS and Other Multiplexed Assays}

The most comprehensive and inclusive method of identifying fusions is through NGS assays such as whole genome, targeted panel, and RNA sequencing (Fig. 4b-d). As the power of NGS 

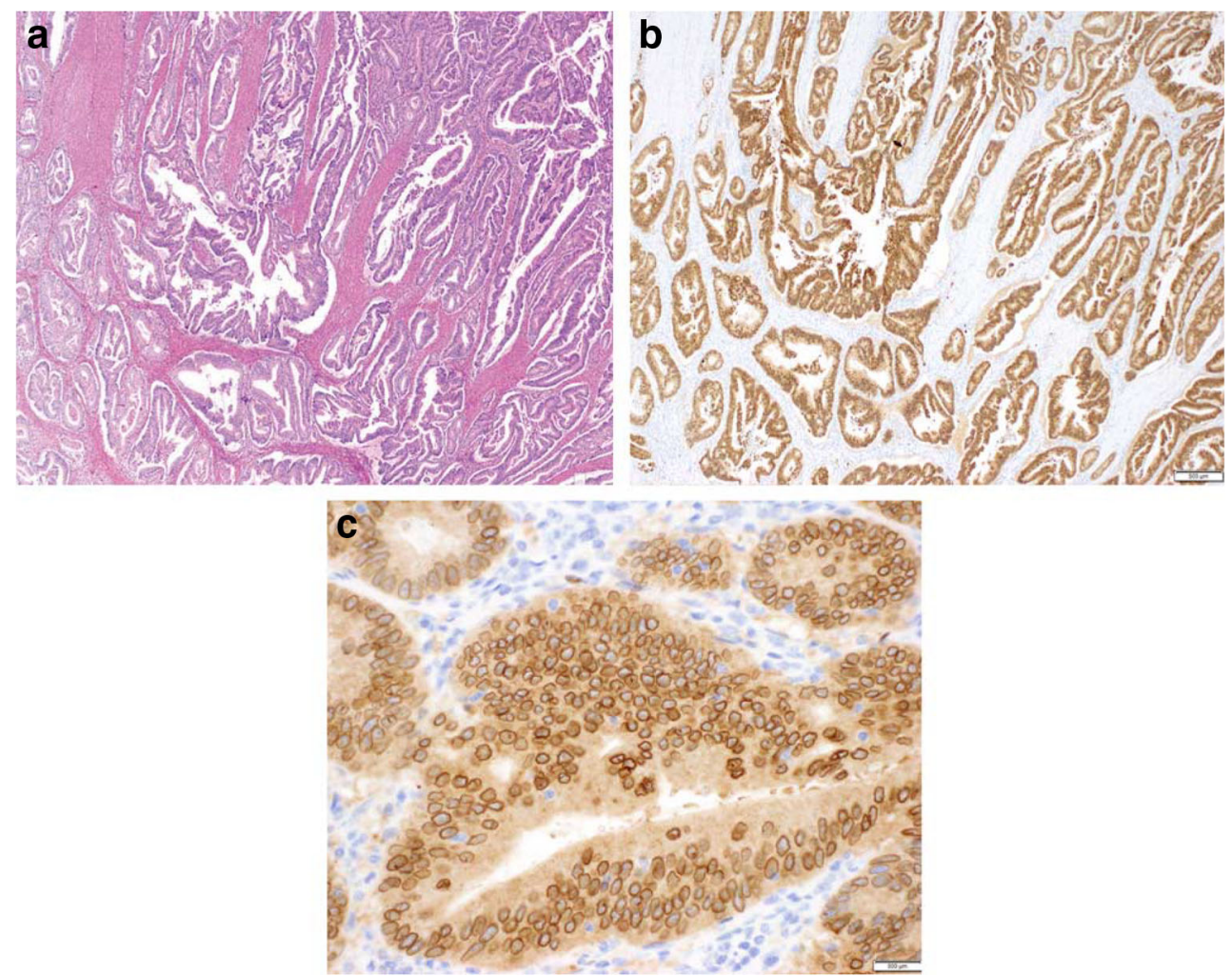

Fig. 5 Example pan-tropomyosin receptor kinase (TRK) immunohistochemistry (IHC) staining pattern in a patient with colorectal carcinoma with an $\boldsymbol{L M N A}$ - NTRK1 fusion [28]. A moderately differentiated colorectal carcinoma with conventional histology (hematoxylin and eosin) and an LMNA exon 12-NTRK1 exon 12 fusion (A) displays diffuse cytoplasmic and nuclear membrane staining for pan-TRK IHC (pan-TRK IHC

technology has increased, the cost of analyzing each sample has also decreased. However, with all NGS-based assays, the need for analytic and bioinformatic support may be prohibitive for many laboratories. Although not primarily used for the detection of fusions, whole genome studies have led to the discovery of novel, recurrent, and rare fusions [82]. The usefulness of these data is limited because, on the genomic level, fusions are often found as passengers of general genomic instability, a hallmark of cancer. However, whole genome, in conjunction with RNA sequencing, has been integral for validating and determining the biological relevance and potential downstream effects of genomic fusions $[82,83]$. Whole-genome sequencing has clear benefits and uses in terms of fusion discovery and basic biology research, although they are currently not suitable as a universal method in a clinical setting due to the intensive bioinformatics required to interpret the data generated.

The most common method of detecting fusion events utilizing NGS is through analyzing a specific panel of genes. The genes to be sequenced are isolated by either an amplicon-based or hybrid capture methodology. Amplicon-based methods enrich for target genes by PCR amplification of a distinct set of genes which requires less input DNA but can only detect fusion partners that are also included in the panel. In contrast, hybrid clone EPR17341, Abcam, Cambridge, MA) (B, C). Reproduced with permission from Hechtman JF, Benayed R, Hyman DM, Drilon A, Zehir A, Frosina D, et al. Am J Surg Pathol 2017;41(11):1547-51. URL: https://journals.lww.com/ajsp/Abstract/2017/11000/Pan_Trk Immunohistochemistry_Is_an_Efficient_and.13.aspx

capture enrichment targets specific genomic regions through hybridization with a substrate (streptavidin/biotin), and thus can be used to identify an unknown fusion linked to the target sequence. Detection can still be challenging with low complexity sequencing, as the breakpoint may be located within a large intron, with adequate coverage costly and potentially unfeasible. This is particularly problematic with NTRK2 and NTRK3 fusion testing by DNA sequencing, with the entire intron sequence needing to be included in testing panels. Lastly, RNAbased panel sequencing provides the most utility by enriching for specific expressed transcripts without the complication of large introns. These panels, such as the Illumina TruSight 170 panel (TST170) and the Archer FusionPlex assay, are designed to target and enrich for hundreds of fusions involving specific genes using hybrid capture and anchored multiplex PCR technologies, respectively [46]. The advantage of this technology is that knowledge of only one of the partners is required, allowing for the potential discovery of novel fusion partners. The use of messenger RNA (mRNA) also provides confidence that the fusion is expressed. However, this method is still limited in that one of the partner genes must be present on the panel.

Although the turnaround time for NGS technology can be long (6-21 days), it provides an extremely comprehensive, 
specific, and sensitive technique with extensive multiplex capabilities. Many of the larger clinical laboratories have moved towards integrating NGS testing into routine clinical workups such as the Memorial Sloan Kettering-Integrated Mutation Profiling of Actionable Cancer Targets (MSK-IMPACT), which has been used since 2014 and was approved by the Food and Drug Administration (FDA) in 2017. The MSK-IMPACT panel is hybrid-capture-based and includes 341 key cancer genes of which 14 are recurrently rearranged genes [69]. However, for many clinical laboratories, the bioinformatics demands, costs, and availability of NGS facilities/personnel can be prohibitive.

Lastly, although not considered NGS, the Nanostring nCounter Vantage 3D is an extensively multiplexed high-throughput hybridization assay that uses targetspecific probes to detect fusion transcripts. Although the Nanostring platform requires more input RNA $\left(\sim 100_{-}\right.$ $300 \mathrm{ng})$ compared to NGS-based panels ( 10-100 ng), this technique does not introduce PCR amplification biases or sequencing errors since the assay uses native, unamplified RNA. Instead, the Nanostring platform detects fusions by using probes that are designed to bind directly to the fusion junction. Therefore, fusions that occur at non-canonical breakpoints or are not present in the panel would not be detected. At this point in time, the existing fusion platform only tests for two specific NTRK1 fusions, although additional assays can be created to detect the full complement of known NTRK gene fusions.

\section{Summary of Testing Methods Used to Identify Patients with TRK Fusion Cancer}

Due to the large variability in NTRK gene fusion partners and the limitations of many of the available testing methods, testing for NTRK gene fusions often makes use of two independent testing methods in order to provide a reliable diagnosis [81]. The method used by nearly all studies has been RNA-based NGS due to the comprehensive and extensively multiplexed nature of this technology. Several studies including the phase I trials for entrectinib have used RNA-based anchor multiplexed NGS to identify gene fusion events in patients followed by FISH confirmation with break-apart probes [84] or IHC [85]. Other studies including the phase II basket STARTRK-2 trial have used a two-step IHC-NGS technique [86]. In this method, IHC screening is performed using a cocktail of pan-tyrosine kinase antibodies that detect expression of TRKA, TRKB, TRKC, ROS1, and ALK followed by NGS using RNA-based anchored multiplex PCR to determine the exact fusion, similarly to the previously mentioned studies. This two-step diagnostic test using IHC as an initial screen followed by NGS appears to be a quick and cost-effective method for screening out NTRK fusion-negative cases. A caveat is that strong IHC staining may also indicate overexpression of wildtype TRK proteins, requiring validation by NGS [86]. Indeed, strong wildtype TRK protein detection is a major caveat of using antibodies alone, which do not discern between wildtype proteins and TRK fusion proteins. Issues with the scoring methods used by pathologists may also lead to these discrepancies with IHC alone. However, if the goal is to solely detect NTRK fusions leading to enhanced TRK expression, the availability of a reliable pan-TRK antibody would be a very useful first step for increasing the detection rate.

\section{NTRK Fusion Testing in Clinical Practice: Challenges and Future Perspectives}

Data from the larotrectinib and entrectinib phase I and II clinical trials have shown durable benefit and welltolerated toxicity, which warrants the introduction of routine testing for NTRK gene fusions. However, challenges persist in incorporating these tests into routine laboratory diagnostics. Notably, oncogenic NTRK gene fusions have been identified in $\sim 1 \%$ of solid tumors [81]. Therefore, routine testing may be limited to tumors where canonical driver mutations are not identified. However, in cancers that are typically driven by oncogenic fusions, including sarcomas, use of targeted sequencing platforms such as Childseq [87], or more recently the extensively multiplexed Nanostring platform, has already been shown to be more cost-effective and comparably reliable in identifying the driver fusion compared to more traditional methods such as IHC, FISH, and RT-PCR [88]. Recent NGS panels such as the Illumina Trusight fusion panel [89] and MSK-IMPACT [90] have also been found to be as effective in detecting gene fusion events involving ROS1, ALK, and RET fusions. These studies provide support towards using NGS molecular assays as routine diagnostic tests in preference to more traditional methods as the costs become lower and the testing panels become more inclusive.

Traditional methods often suffer from limitations. IHC relies on the availability and efficacy of antibodies, which can vary greatly from lot-to-lot and does not conclusively identify the presence of a fusion protein. However, this variability might be mitigated by the availability of the panTRK IHC assay from Ventana. FISH relies on human interpretation of the fluorescent signals and cannot be multiplexed, and RT-PCR requires knowledge of the fusion junction. The greatest barriers to routine use of NGS assays are the need for stringent validation of results over the traditional methods and the bioinformatic pipeline/expertise required for analyzing the data. Many companies and third parties have begun to address the bioinformatic issue by 
creating user-friendly software to accompany their assays, allowing for rapid and straightforward analysis of the data generated. Although globally available, country and regional variations in access to NGS testing and the high costs of testing may pose challenges for ensuring broad patient access to these tests.

\section{Conclusions}

NTRK gene fusions have garnered much clinical attention recent years due to the efficacy of small molecule inhibitors such as the recently FDA-approved use of larotrectinib (Vitrakvi ${ }^{\circledR}$ ) and entrectinib in clinical trials. These drugs have also shown penetrance through the blood-brain barrier which will provide much-needed therapeutic options to patients with CNS malignancies, a field which has struggled to find durable and effective treatment options. NTRK gene fusions have been identified using several different approaches including FISH, RT-PCR, and NGS. IHC provides a useful screening technique to identify tumors with potential NTRK gene fusions that warrant further confirmation with NGS or other robust techniques, but there is a need to overcome the lack of sensitivity to detect fusions involving NTRK3. NTRK gene fusions have been identified in a broad range of cancers and appear to be tumor agnostic driver events. Although they may only be present in a small proportion of tumors, identifying these patients will be crucial for providing precision therapeutic options going forward. Therefore, robust testing methods are essential to identify the patients that harbor TRK fusion cancer in order to provide them with the benefit of precision medicine.

Acknowledgements This work was supported in part by funds from CIHR Foundation grant FDN-143280 (to PHS), BrainCare BC (to SY), and the BC Cancer Foundation (to PHS). Medical writing support, including assisting authors with the development of the outline and initial draft, incorporation of comments and preparation of tables and figures, was provided by Cindy Cheung, MBBS, and Alison Scott, PhD; editorial support, including fact-checking, referencing, figure preparation, formatting, proofreading and submission was provided by Annabel Ola, MSc; all of Scion (London, UK), supported by Bayer Healthcare according to Good Publication Practice guidelines (http://annals.org/aim/article/ 2424869/good-publication-practice-communicating-companysponsored-medical-research-gpp3).

\section{Compliance with Ethical Standards}

Conflict of Interest Dr. Wong declares no conflicts of interest. Dr. Yip declares consultation fees from Bayer and Pfizer for his participation in advisory boards and travel expense reimbursement from Roche/ Foundation Medicine. Dr. Sorensen declares that he is an advisor for Bayer Pharmaceuticals but holds no financial interest in the company.

Ethical Approval This article does not contain any studies with human participants or animals performed by any of the authors.
Open Access This article is distributed under the terms of the Creative Commons Attribution 4.0 International License (http:// creativecommons.org/licenses/by/4.0/), which permits unrestricted use, distribution, and reproduction in any medium, provided you give appropriate credit to the original author(s) and the source, provide a link to the Creative Commons license, and indicate if changes were made.

\section{References}

1. Maruyama I (2014) Mechanisms of activation of receptor tyrosine kinases: monomers or dimers. Cells 3(2):304-330

2. Arevalo JC, Wu SH (2006) Neurotrophin signaling: many exciting surprises! Cell Mol Life Sci 63(13):1523-1537. https://doi.org/10. 1007/s00018-006-6010-1

3. Nakagawara A (2001) Trk receptor tyrosine kinases: a bridge between cancer and neural development. Cancer Lett 169(2):107-114

4. Huang EJ, Reichardt LF (2003) Trk receptors: roles in neuronal signal transduction. Annu Rev Biochem 72:609-642. https://doi. org/10.1146/annurev.biochem.72.121801.161629

5. Amatu A, Sartore-Bianchi A, Siena S (2016) NTRK gene fusions as novel targets of cancer therapy across multiple tumour types. ESMO Open 1(2):e000023. https://doi.org/10.1136/esmoopen2015-000023

6. Medves S, Demoulin JB (2012) Tyrosine kinase gene fusions in cancer: translating mechanisms into targeted therapies. J Cell Mol Med 16(2):237-248. https://doi.org/10.1111/j.1582-4934.2011. 01415.x

7. Wai DH, Knezevich SR, Lucas T, Jansen B, Kay RJ, Sorensen PHB (2000) The ETV6-NTRK3 gene fusion encodes a chimeric protein tyrosine kinase that transforms NIH3T3 cells. Oncogene 19(7): 906-915. https://doi.org/10.1038/sj.onc.1203396

8. Vaishnavi A, Le AT, Doebele RC (2015) TRKing down an old oncogene in a new era of targeted therapy. Cancer Discov 5(1): 25-34. https://doi.org/10.1158/2159-8290.Cd-14-0765

9. Triche TJ, Hicks MJ, Sorensen PH (2015) Diagnostic pathology of pediatric malignancies. In: Pizzo PA, Poplack DG (eds) Principles and practice of pediatric oncology, 7th Edition. Wolters Kluwer Health

10. Martin-Zanca D, Hughes SH, Barbacid M (1986) A human oncogene formed by the fusion of truncated tropomyosin and protein tyrosine kinase sequences. Nature 319(6056):743-748. https://doi. org $/ 10.1038 / 319743 \mathrm{a} 0$

11. Knezevich SR, McFadden DE, Tao W, Lim JF, Sorensen PH (1998) A novel ETV6-NTRK3 gene fusion in congenital fibrosarcoma. Nat Genet 18(2):184-187. https://doi.org/10.1038/ng0298-184

12. Knezevich SR, Garnett MJ, Pysher TJ, Beckwith JB, Grundy PE, Sorensen PH (1998) ETV6-NTRK3 gene fusions and trisomy 11 establish a histogenetic link between mesoblastic nephroma and congenital fibrosarcoma. Cancer Res 58(22):5046-5048

13. Rubin BP, Chen CJ, Morgan TW, Xiao S, Grier HE, Kozakewich HP, Perez-Atayde AR, Fletcher JA (1998) Congenital mesoblastic nephroma $t(12 ; 15)$ is associated with ETV6-NTRK3 gene fusion: cytogenetic and molecular relationship to congenital (infantile) fibrosarcoma. Am J Pathol 153(5):1451-1458. https://doi.org/10. 1016/S0002-9440(10)65732-X

14. Tognon C, Knezevich SR, Huntsman D, Roskelley CD, Melnyk N, Mathers JA, Becker L, Carneiro F, MacPherson N, Horsman D, Poremba C, Sorensen PH (2002) Expression of the ETV6NTRK3 gene fusion as a primary event in human secretory breast carcinoma. Cancer Cell 2(5):367-376

15. Eguchi M, Eguchi-Ishimae M, Tojo A, Morishita K, Suzuki K, Sato Y, Kudoh S, Tanaka K, Setoyama M, Nagamura F, Asano S, 
Kamada N (1999) Fusion of ETV6 to neurotrophin-3 receptor TRKC in acute myeloid leukemia with $\mathrm{t}(12 ; 15)(\mathrm{p} 13 ; \mathrm{q} 25)$. Blood 93(4):1355-1363

16. Leeman-Neill RJ, Kelly LM, Liu P, Brenner AV, Little MP, Bogdanova TI, Evdokimova VN, Hatch M, Zurnadzy LY, Nikiforova MN, Yue NJ, Zhang M, Mabuchi K, Tronko MD, Nikiforov YE (2014) ETV6-NTRK3 is a common chromosomal rearrangement in radiation-associated thyroid cancer. Cancer 120(6):799-807. https://doi.org/10.1002/cncr.28484

17. Wu G, Diaz AK, Paugh BS, Rankin SL, Ju B, Li Y, Zhu X, Qu C, Chen X, Zhang J, Easton J, Edmonson M, Ma X, Lu C, Nagahawatte P, Hedlund E, Rusch M, Pounds S, Lin T, OnarThomas A, Huether R, Kriwacki R, Parker M, Gupta P, Becksfort J, Wei L, Mulder HL, Boggs K, Vadodaria B, Yergeau D, Russell JC, Ochoa K, Fulton RS, Fulton LL, Jones C, Boop FA, Broniscer A, Wetmore C, Gajjar A, Ding L, Mardis ER, Wilson RK, Taylor MR, Downing JR, Ellison DW, Zhang J, Baker SJ (2014) The genomic landscape of diffuse intrinsic pontine glioma and pediatric non-brainstem high-grade glioma. Nat Genet 46(5):444-450. https://doi.org/10.1038/ng.2938

18. El Demellawy D, Cundiff CA, Nasr A, Ozolek JA, Elawabdeh N, Caltharp SA, Masoudian P, Sullivan KJ, de Nanassy J, Shehata BM (2016) Congenital mesoblastic nephroma: a study of 19 cases using immunohistochemistry and ETV6-NTRK3 fusion gene rearrangement. Pathology 48(1):47-50. https://doi.org/10.1016/j.pathol. 2015.11.007

19. Skalova A, Vanecek T, Sima R, Laco J, Weinreb I, Perez-Ordonez B, Starek I, Geierova M, Simpson RH, Passador-Santos F, Ryska A, Leivo I, Kinkor Z, Michal M (2010) Mammary analogue secretory carcinoma of salivary glands, containing the ETV6-NTRK3 fusion gene: a hitherto undescribed salivary gland tumor entity. Am J Surg Pathol 34(5):599-608. https://doi.org/10.1097/PAS. 0b013e3181d9efcc

20. Bourgeois JM, Knezevich SR, Mathers JA, Sorensen PH (2000) Molecular detection of the ETV6-NTRK3 gene fusion differentiates congenital fibrosarcoma from other childhood spindle cell tumors. Am J Surg Pathol 24(7):937-946

21. Sartore-Bianchi A, Ardini E, Bosotti R, Amatu A, Valtorta E, Somaschini A, Raddrizzani L, Palmeri L, Banfi P, Bonazzina E, Misale S, Marrapese G, Leone A, Alzani R, Luo D, Hornby Z, Lim J, Veronese S, Vanzulli A, Bardelli A, Martignoni M, Davite C, Galvani A, Isacchi A, Siena S (2016) Sensitivity to entrectinib associated with a novel LMNA-NTRK1 gene fusion in metastatic colorectal cancer. J Natl Cancer Inst 108(1). https://doi.org/10. 1093/jnci/djv306

22. Drilon A, Siena S, Ou SI, Patel M, Ahn MJ, Lee J, Bauer TM, Farago AF, Wheler JJ, Liu SV, Doebele R, Giannetta L, Cerea G, Marrapese G, Schirru M, Amatu A, Bencardino K, Palmeri L, Sartore-Bianchi A, Vanzulli A, Cresta S, Damian S, Duca M, Ardini E, Li G, Christiansen J, Kowalski K, Johnson AD, Patel R, Luo D, ChowManeval E, Hornby Z, Multani PS, Shaw AT, De Braud FG (2017) Safety and antitumor activity of the multitargeted pan-TRK, ROS1, and ALK inhibitor entrectinib: combined results from two phase I trials (ALKA-372-001 and STARTRK-1). Cancer Discov 7(4):400409. https://doi.org/10.1158/2159-8290.CD-16-1237

23. Drilon A, Laetsch TW, Kummar S, DuBois SG, Lassen UN, Demetri GD, Nathenson M, Doebele RC, Farago AF, Pappo AS, Turpin B, Dowlati A, Brose MS, Mascarenhas L, Federman N, Berlin J, El-Deiry WS, Baik C, Deeken J, Boni V, Nagasubramanian R, Taylor M, Rudzinski ER, Meric-Bernstam F, Sohal DPS, Ma PC, Raez LE, Hechtman JF, Benayed R, Ladanyi M, Tuch BB, Ebata K, Cruickshank S, Ku NC, Cox MC, Hawkins DS, Hong DS, Hyman DM (2018) Efficacy of larotrectinib in TRK fusion-positive cancers in adults and children. N Engl J Med 378(8):731-739. https://doi.org/10.1056/ NEJMoa1714448
24. Kummar S, Lassen UN (2018) TRK inhibition: a new tumoragnostic treatment strategy. Target Oncol 13(5):545-556. https:// doi.org/10.1007/s11523-018-0590-1

25. Lezcano C, Shoushtari AN, Ariyan C, Hollmann TJ, Busam KJ (2018) Primary and metastatic melanoma with NTRK fusions. Am J Surg Pathol 42(8):1052-1058. https://doi.org/10.1097/PAS. 0000000000001070

26. Prabhakaran N, Guzman MA, Navalkele P, Chow-Maneval E, Batanian JR (2018) Novel TLE4-NTRK2 fusion in a ganglioglioma identified by array-CGH and confirmed by NGS: potential for a gene targeted therapy. Neuropathology 38:380-386. https://doi. org/10.1111/neup. 12458

27. Chmielecki J, Bailey M, He J, Elvin J, Vergilio JA, Ramkissoon S, Suh J, Frampton GM, Sun JX, Morley S, Spritz D, Ali S, Gay L, Erlich RL, Ross JS, Buxhaku J, Davies H, Faso V, Germain A, Glanville B, Miller VA, Stephens PJ, Janeway KA, Maris JM, Meshinchi S, Pugh TJ, Shern JF, Lipson D (2017) Genomic profiling of a large set of diverse pediatric cancers identifies known and novel mutations across tumor spectra. Cancer Res 77(2):509-519. https://doi.org/10.1158/0008-5472.CAN-16-1106

28. Hechtman JF, Benayed R, Hyman DM, Drilon A, Zehir A, Frosina D, Arcila ME, Dogan S, Klimstra DS, Ladanyi M, Jungbluth AA (2017) Pan-Trk immunohistochemistry is an efficient and reliable screen for the detection of NTRK fusions. Am J Surg Pathol 41(11): 1547-1551. https://doi.org/10.1097/PAS.0000000000000911

29. Milione M, Ardini E, Christiansen J, Valtorta E, Veronese S, Bosotti R, Pellegrinelli A, Testi A, Pietrantonio F, Fuca G, Wei G, Murphy D, Siena S, Isacchi A, De Braud F (2017) Identification and characterization of a novel SCYL3-NTRK1 rearrangement in a colorectal cancer patient. Oncotarget 8(33):55353-55360. https://doi.org/ 10.18632/oncotarget.19512

30. Edgren H OK, Ruusulehto A, Ganji G (2015) Rapid pan-cancer identification of previously unidentified fusion genes to enable novel targeted therapeutics. Proceedings: AACR 106th annual meeting 2015. 75:suppl 15; abstract 4793

31. Kim J, Lee Y, Cho HJ, Lee YE, An J, Cho GH, Ko YH, Joo KM, Nam DH (2014) NTRK1 fusion in glioblastoma multiforme. PLoS One 9(3):e91940. https://doi.org/10.1371/journal.pone.0091940

32. Sigal D, Tartar M, Xavier M, Bao F, Foley P, Luo D, Christiansen J, Hornby Z, Maneval EC, Multani P (2017) Activity of Entrectinib in a patient with the first reported NTRK fusion in neuroendocrine Cancer. Journal of the National Comprehensive Cancer Network : JNCCN 15(11):1317-1322. https://doi.org/10.6004/jnccn.2017.7029

33. Stransky N, Cerami E, Schalm S, Kim JL, Lengauer C (2014) The landscape of kinase fusions in cancer. Nat Commun 5:4846. https:// doi.org/10.1038/ncomms5846

34. Church AJ, Calicchio ML, Nardi V, Skalova A, Pinto A, Dillon DA, Gomez-Fernandez CR, Manoj N, Haimes JD, Stahl JA, Dela Cruz FS, Tannenbaum-Dvir S, Glade-Bender JL, Kung AL, DuBois SG, Kozakewich HP, Janeway KA, Perez-Atayde AR, Harris MH (2018) Recurrent EML4-NTRK3 fusions in infantile fibrosarcoma and congenital mesoblastic nephroma suggest a revised testing strategy. Modern pathology : an official journal of the United States and Canadian academy of. Pathology, Inc 31(3):463-473. https://doi.org/10.1038/modpathol.2017.127

35. Lee SJ, Li GG, Kim ST, Hong ME, Jang J, Yoon N, Ahn SM, Murphy D, Christiansen J, Wei G, Hornby Z, Lee DW, Park JO, Park YS, Lim HY, Hong SN, Kim SH, Kang WK, Park K, Park WY, Kim KM, Lee J (2015) NTRK1 rearrangement in colorectal cancer patients: evidence for actionable target using patient-derived tumor cell line. Oncotarget 6(36):39028-39035. https://doi.org/10. 18632/oncotarget.5494

36. Brenca M, Rossi S, Polano M, Gasparotto D, Zanatta L, Racanelli D, Valori L, Lamon S, Dei Tos AP, Maestro R (2016) Transcriptome sequencing identifies ETV6-NTRK3 as a gene 
fusion involved in GIST. J Pathol 238(4):543-549. https://oi.org/ 10.1002/path.4677

37. Yoshihara K, Wang Q, Torres-Garcia W, Zheng S, Vegesna R, Kim $\mathrm{H}$, Verhaak RG (2015) The landscape and therapeutic relevance of cancer-associated transcript fusions. Oncogene 34(37):4845-4854. https://doi.org/10.1038/onc.2014.406

38. Jones DT, Hutter B, Jager N, Korshunov A, Kool M, Warnatz HJ, Zichner T, Lambert SR, Ryzhova M, Quang DA, Fontebasso AM, Stutz AM, Hutter S, Zuckermann M, Sturm D, Gronych J, Lasitschka B, Schmidt S, Seker-Cin H, Witt H, Sultan M, Ralser M, Northcott PA, Hovestadt V, Bender S, Pfaff E, Stark S, Faury D, Schwartzentruber J, Majewski J, Weber UD, Zapatka M, Raeder B, Schlesner M, Worth CL, Bartholomae CC, von Kalle C, Imbusch CD, Radomski S, Lawerenz C, van Sluis P, Koster J, Volckmann R, Versteeg R, Lehrach H, Monoranu C, Winkler B, Unterberg A, Herold-Mende C, Milde T, Kulozik AE, Ebinger M, Schuhmann MU, Cho YJ, Pomeroy SL, von Deimling A, Witt O, Taylor MD, Wolf S, Karajannis MA, Eberhart CG, Scheurlen W, Hasselblatt M, Ligon KL, Kieran MW, Korbel JO, Yaspo ML, Brors B, Felsberg J, Reifenberger G, Collins VP, Jabado N, Eils R, Lichter P, Pfister SM, International Cancer Genome Consortium PedBrain Tumor $\mathrm{P}$ (2013) Recurrent somatic alterations of FGFR1 and NTRK2 in pilocytic astrocytoma. Nat Genet 45(8):927-932. https://doi.org/ 10.1038/ng.2682

39. Roberts KG, Li Y, Payne-Turner D, Harvey RC, Yang YL, Pei D, McCastlain K, Ding L, Lu C, Song G, Ma J, Becksfort J, Rusch M, Chen SC, Easton J, Cheng J, Boggs K, Santiago-Morales N, Iacobucci I, Fulton RS, Wen J, Valentine M, Cheng C, Paugh SW, Devidas M, Chen IM, Reshmi S, Smith A, Hedlund E, Gupta P, Nagahawatte P, Wu G, Chen X, Yergeau D, Vadodaria B, Mulder H, Winick NJ, Larsen EC, Carroll WL, Heerema NA, Carroll AJ, Grayson G, Tasian SK, Moore AS, Keller F, Frei-Jones M, Whitlock JA, Raetz EA, White DL, Hughes TP, Guidry Auvil JM, Smith MA, Marcucci G, Bloomfield CD, Mrozek K, Kohlschmidt J, Stock W, Kornblau SM, Konopleva M, Paietta E, Pui CH, Jeha S, Relling MV, Evans WE, Gerhard DS, GastierFoster JM, Mardis E, Wilson RK, Loh ML, Downing JR, Hunger SP, Willman CL, Zhang J, Mullighan CG (2014) Targetable kinaseactivating lesions in $\mathrm{Ph}$-like acute lymphoblastic leukemia. $\mathrm{N}$ Engl J Med 371(11):1005-1015. https://doi.org/10.1056/ NEJMoa1403088

40. George J, Walter V, Peifer M, Alexandrov LB, Seidel D, Leenders F, Maas L, Muller C, Dahmen I, Delhomme TM, Ardin M, Leblay N, Byrnes G, Sun R, De Reynies A, McLeer-Florin A, Bosco G, Malchers F, Menon R, Altmuller J, Becker C, Nurnberg P, Achter V, Lang U, Schneider PM, Bogus M, Soloway MG, Wilkerson MD, Cun Y, McKay JD, Moro-Sibilot D, Brambilla CG, Lantuejoul S, Lemaitre N, Soltermann A, Weder W, Tischler V, Brustugun OT, Lund-Iversen M, Helland A, Solberg S, Ansen S, Wright G, Solomon B, Roz L, Pastorino U, Petersen I, Clement JH, Sanger J, Wolf J, Vingron M, Zander T, Perner S, Travis WD, Haas SA, Olivier M, Foll M, Buttner R, Hayes DN, Brambilla E, FernandezCuesta L, Thomas RK (2018) Integrative genomic profiling of large-cell neuroendocrine carcinomas reveals distinct subtypes of high-grade neuroendocrine lung tumors. Nat Commun 9(1):1048. https://doi.org/10.1038/s41467-018-03099-x

41. Ronsley R, Rassekh SR, Shen Y, Lee AF, Jantzen C, Halparin J, Albert C, Hawkins DS, Amed S, Rothstein R, Mungall AJ, Dix D, Blair G, Nadel H, Jones SJM, Laskin J, Marra MA, JD R (2018) Application of genomics to identify therapeutic targets in recurrent pediatric papillary thyroid carcinoma. Cold Spring Harb Mol Case Stud 4(2):a002568. https://doi.org/10.1101/mcs.a002568

42. Hartmaier RJ, Albacker LA, Chmielecki J, Bailey M, He J, Goldberg ME, Ramkissoon S, Suh J, Elvin JA, Chiacchia S, Frampton GM, Ross JS, Miller V, Stephens PJ, Lipson D (2017) High-throughput genomic profiling of adult solid tumors reveals novel insights into Cancer pathogenesis. Cancer Res 77(9):2464 2475. https://doi.org/10.1158/0008-5472.CAN-16-2479

43. Ross JS, Wang K, Gay L, Al-Rohil R, Rand JV, Jones DM, Lee HJ, Sheehan CE, Otto GA, Palmer G, Yelensky R, Lipson D, Morosini D, Hawryluk M, Catenacci DV, Miller VA, Churi C, Ali S, Stephens PJ (2014) New routes to targeted therapy of intrahepatic cholangiocarcinomas revealed by next-generation sequencing. Oncologist 19(3):235-242. https://doi.org/10.1634/theoncologist. 2013-0352

44. Shi E, Chmielecki J, Tang CM, Wang K, Heinrich MC, Kang G, Corless CL, Hong D, Fero KE, Murphy JD, Fanta PT, Ali SM, De Siena M, Burgoyne AM, Movva S, Madlensky L, Heestand GM, Trent JC, Kurzrock R, Morosini D, Ross JS, Harismendy O, Sicklick JK (2016) FGFR1 and NTRK3 actionable alterations in "wild-type" gastrointestinal stromal tumors. J Transl Med 14(1): 339. https://doi.org/10.1186/s12967-016-1075-6

45. Wiesner T, He J, Yelensky R, Esteve-Puig R, Botton T, Yeh I, Lipson D, Otto G, Brennan K, Murali R, Garrido M, Miller VA, Ross JS, Berger MF, Sparatta A, Palmedo G, Cerroni L, Busam KJ, Kutzner H, Cronin MT, Stephens PJ, Bastian BC (2014) Kinase fusions are frequent in Spitz tumours and spitzoid melanomas. Nat Commun 5:3116. https://doi.org/10.1038/ncomms4116

46. Zheng Z, Liebers M, Zhelyazkova B, Cao Y, Panditi D, Lynch KD, Chen J, Robinson HE, Shim HS, Chmielecki J, Pao W, Engelman JA, Iafrate AJ, Le LP (2014) Anchored multiplex PCR for targeted next-generation sequencing. Nat Med 20(12):1479-1484. https:// doi.org/10.1038/nm.3729

47. Liang J, Cai W, Feng D, Teng H, Mao F, Jiang Y, Hu S, Li X, Zhang Y, Liu B, Sun ZS (2018) Genetic landscape of papillary thyroid carcinoma in the Chinese population. J Pathol 244(2):215-226. https://doi.org/10.1002/path.5005

48. Vaishnavi A, Capelletti M, Le AT, Kako S, Butaney M, Ercan D, Mahale S, Davies KD, Aisner DL, Pilling AB, Berge EM, Kim J, Sasaki H, Park S, Kryukov G, Garraway LA, Hammerman PS, Haas J, Andrews SW, Lipson D, Stephens PJ, Miller VA, VarellaGarcia M, Janne PA, Doebele RC (2013) Oncogenic and drugsensitive NTRK1 rearrangements in lung cancer. Nat Med 19(11): 1469-1472. https://doi.org/10.1038/nm.3352

49. Chiang S, Cotzia P, Hyman DM, Drilon A, Tap WD, Zhang L, Hechtman JF, Frosina D, Jungbluth AA, Murali R, Park KJ, Soslow RA, Oliva E, Iafrate AJ, Benayed R, Ladanyi M, Antonescu CR (2018) NTRK fusions define a novel uterine sarcoma subtype with features of Fibrosarcoma. Am J Surg Pathol 42(6): 791-798. https://doi.org/10.1097/PAS.0000000000001055

50. Tognon C, Garnett M, Kenward E, Kay R, Morrison K, Sorensen PHB (2001) The chimeric protein tyrosine kinase ETV6-NTRK3 requires both Ras-Erk1/2 and PI3-kinase-Akt signaling for fibroblast transformation. Cancer Res 61(24):8909-8916

51. Tognon CE, Mackereth CD, Somasiri AM, McIntosh LP, Sorensen PHB (2004) Mutations in the SAM domain of the ETV6-NTRK3 chimeric tyrosine kinase block polymerization and transformation activity. Mol Cell Biol 24(11):4636-4650. https://doi.org/10.1128/ mcb.24.11.4636-4650.2004

52. Li Z, Tognon CE, Godinho FJ, Yasaitis L, Hock H, Herschkowitz JI, Lannon CL, Cho E, Kim SJ, Bronson RT, Perou CM, Sorensen PH, Orkin SH (2007) ETV6-NTRK3 fusion oncogene initiates breast cancer from committed mammary progenitors via activation of AP1 complex. Cancer Cell 12(6):542-558. https://doi.org/10. 1016/j.ccr.2007.11.012

53. Morrison KB, Tognon CE, Garnett MJ, Deal C, Sorensen PH (2002) ETV6-NTRK3 transformation requires insulin-like growth factor 1 receptor signaling and is associated with constitutive IRS-1 tyrosine phosphorylation. Oncogene 21(37):5684-5695. https:// doi.org/10.1038/sj.onc. 1205669

54. Martin MJ, Melnyk N, Pollard M, Bowden M, Leong H, Podor TJ, Gleave M, Sorensen PH (2006) The insulin-like growth factor I 
receptor is required for Akt activation and suppression of anoikis in cells transformed by the ETV6-NTRK3 chimeric tyrosine kinase. Mol Cell Biol 26(5):1754-1769. https://doi.org/10.1128/MCB.26. 5.1754-1769.2006

55. Tognon CE, Rafn B, Cetinbas NM, Kamura T, Trigo G, Rotblat B, Okumura F, Matsumoto M, Chow C, Davare M, Pollak M, Mayor T, Sorensen PH (2018) Insulin-like growth factor 1 receptor stabilizes the ETV6-NTRK3 chimeric oncoprotein by blocking its $\mathrm{KPC} 1 /$ Rnf123-mediated proteasomal degradation. J Biol Chem 293(32):12502-12515. https://doi.org/10.1074/jbc.RA117.000321

56. Kheder ES, Hong DS (2018) Emerging targeted therapy for tumors with NTRK fusion proteins. Clin Cancer Res:Clincanres 1156: 2018. https://doi.org/10.1158/1078-0432.ccr-18-1156

57. Liu D, Offin M, Harnicar S, Li BT, Drilon A (2018) Entrectinib: an orally available, selective tyrosine kinase inhibitor for the treatment of NTRK, ROS1, and ALK fusion-positive solid tumors. Ther Clin Risk Manag 14:1247-1252. https://doi.org/10.2147/TCRM. S147381

58. Ziegler DS, Wong M, Mayoh C, Kumar A, Tsoli M, Mould E, Tyrrell V, Khuong-Quang DA, Pinese M, Gayevskiy V, Cohn RJ, Lau LMS, Reynolds M, Cox MC, Gifford A, Rodriguez M, Cowley MJ, Ekert PG, Marshall GM, Haber M (2018) Brief report: potent clinical and radiological response to larotrectinib in TRK fusiondriven high-grade glioma. Br J Cancer 119(6):693-696. https://doi. org/10.1038/s41416-018-0251-2

59. Laetsch TW, DuBois SG, Mascarenhas L, Turpin B, Federman N, Albert CM, Nagasubramanian R, Davis JL, Rudzinski E, Feraco AM, Tuch BB, Ebata KT, Reynolds M, Smith S, Cruickshank S, Cox MC, Pappo AS, Hawkins DS (2018) Larotrectinib for paediatric solid tumours harbouring NTRK gene fusions: phase 1 results from a multicentre, open-label, phase $1 / 2$ study. The Lancet Oncology 19(5):705-714. https://doi.org/10.1016/s1470-2045(18) 30119-0

60. U.S. Food \& Drug Administration. Drugs@FDA: FDA Approved Drug Products. https://www.accessdata.fda.gov/scripts/cder/daf/ index.cfm? event $=$ overview.process \&varApplNo=210861. [Accessed 12 March 2019]

61. Cui C, Shu W, Li P (2016) Fluorescence in situ hybridization: cellbased genetic diagnostic and research applications. Frontiers in cell and developmental biology 4:89. https://doi.org/10.3389/fcell. 2016.00089

62. Argani P, Fritsch M, Kadkol SS, Schuster A, Beckwith JB, Perlman EJ (2000) Detection of the ETV6-NTRK3 chimeric RNA of infantile fibrosarcoma/cellular congenital mesoblastic nephroma in paraffin-embedded tissue: application to challenging pediatric renal stromal tumors. Modern pathology : an official journal of the United States and Canadian academy of Pathology, Inc 13 (1):2936. https://doi.org/10.1038/modpathol.3880006

63. Kumar S, Razzaq SK, Vo AD, Gautam M, Li H (2016) Identifying fusion transcripts using next generation sequencing. Wiley interdisciplinary reviews RNA 7(6):811-823. https://doi.org/10.1002/ wrna. 1382

64. Doshi S, Ray D, Stein K, Zhang J, Koduru P, Fogt F, Wellman A, Wat R, Mathews C (2016) Economic analysis of alternative strategies for detection of ALK rearrangements in non small cell lung Cancer. Diagnostics (Basel) 6(1). https://doi.org/10.3390/ diagnostics6010004

65. Davies KD, Le AT, Sheren J, Nijmeh H, Gowan K, Jones KL, Varella-Garcia M, Aisner DL, Doebele RC (2018) Comparison of molecular testing modalities for detection of ROS1 rearrangements in a cohort of positive patient samples. J Thorac Oncol 13(10): 1474-1482. https://doi.org/10.1016/j.jtho.2018.05.041

66. Godbey P, Myles JL, Black-Schaffer WS, Scott J Pathology payment - An overview of the 2018 proposed Medicare physician fee schedule. College of American Pathologists https://documents.cap. org/documents/pathology-payment.pdf. [Accessed 12 March 2019]
67. Helman E, Nguyen M, Karlovich CA, Despain D, Choquette AK, Spira AI, Yu HA, Camidge DR, Harding TC, Lanman RB, Simmons AD (2018) Cell-free DNA Next-generation sequencing prediction of response and resistance to third-generation EGFR inhibitor. Clin Lung Cancer 19(6):518-530 e517. https://doi.org/10. 1016/j.cllc.2018.07.008

68. Bubendorf L, Buttner R, Al-Dayel F, Dietel M, Elmberger G, Kerr K, Lopez-Rios F, Marchetti A, Oz B, Pauwels P, Penault-Llorca F, Rossi G, Ryska A, Thunnissen E (2016) Testing for ROS1 in nonsmall cell lung cancer: a review with recommendations. Virchows Arch 469(5):489-503. https://doi.org/10.1007/s00428-016-2000-3

69. Cheng DT, Mitchell TN, Zehir A, Shah RH, Benayed R, Syed A, Chandramohan R, Liu ZY, Won HH, Scott SN, Brannon AR, O'Reilly C, Sadowska J, Casanova J, Yannes A, Hechtman JF, Yao J, Song W, Ross DS, Oultache A, Dogan S, Borsu L, Hameed M, Nafa K, Arcila ME, Ladanyi M, Berger MF (2015) Memorial Sloan Kettering-integrated mutation profiling of actionable Cancer targets (MSK-IMPACT). a hybridization capture-based next-generation sequencing clinical assay for solid tumor molecular oncology J Mol Diagn 17(3):251-264. https://doi.org/10.1016/j. jmoldx.2014.12.006

70. Mullin E Next Generation sequencing in the clinical laboratory: in the trenches with early adopters. https://www.aacc.org/publications/ $\mathrm{cln} /$ articles/2015/may/next-generation-sequencing-in-the-clinicallaboratory. [Accessed 12 March 2019]

71. Sabari JK, Santini F, Bergagnini I, Lai WV, Arbour KC, Drilon A (2017) Changing the therapeutic landscape in non-small cell lung cancers: the evolution of comprehensive molecular profiling improves access to therapy. Curr Oncol Rep 19(4):24. https://doi. org/10.1007/s11912-017-0587-4

72. Paasinen-Sohns A, Koelzer VH, Frank A, Schafroth J, Gisler A, Sachs M, Graber A, Rothschild SI, Wicki A, Cathomas G, Mertz KD (2017) Single-center experience with a targeted Next generation sequencing assay for assessment of relevant somatic alterations in solid tumors. Neoplasia 19(3):196-206. https://doi.org/10.1016/ j.neo.2017.01.003

73. Wegert J, Vokuhl C, Collord G, Del Castillo Velasco-Herrera M, Farndon SJ, Guzzo C, Jorgensen M, Anderson J, Slater O, Duncan C, Bausenwein S, Streitenberger H, Ziegler B, Furtwangler R, Graf N, Stratton MR, Campbell PJ, Jones DT, Koelsche C, Pfister SM, Mifsud W, Sebire N, Sparber-Sauer M, Koscielniak E, Rosenwald A, Gessler M, Behjati S (2018) Recurrent intragenic rearrangements of EGFR and BRAF in soft tissue tumors of infants. Nat Commun 9(1):2378. https://doi.org/10.1038/s41467-018-04650-6

74. van den Akker J, Mishne G, Zimmer AD, Zhou AY (2018) A machine learning model to determine the accuracy of variant calls in capture-based next generation sequencing. BMC Genomics 19(1):263. https://doi.org/10.1186/s12864-018-4659-0

75. Tkachuk DC, Westbrook CA, Andreeff M, Donlon TA, Cleary ML, Suryanarayan K, Homge M, Redner A, Gray J, Pinkel D (1990) Detection of bcr-abl fusion in chronic myelogeneous leukemia by in situ hybridization. Science 250(4980):559-562

76. Doebele RC, Davis LE, Vaishnavi A, Le AT, Estrada-Bernal A, Keysar S, Jimeno A, Varella-Garcia M, Aisner DL, Li Y, Stephens PJ, Morosini D, Tuch BB, Fernandes M, Nanda N, Low JA (2015) An oncogenic NTRK fusion in a patient with soft-tissue sarcoma with response to the tropomyosin-related kinase inhibitor LOXO-101. Cancer Discov 5(10):1049-1057. https://doi.org/10. 1158/2159-8290.Cd-15-0443

77. Lyu X, Wang X, Zhang L, Chen Z, Zhao Y, Hu J, Fan R, Song Y (2017) Detection of 22 common leukemic fusion genes using a single-step multiplex qRT-PCR-based assay. Diagn Pathol 12(1): 55. https://doi.org/10.1186/s13000-017-0634-3

78. Wu YC, Chang IC, Wang CL, Chen TD, Chen YT, Liu HP, Chu Y, Chiu YT, Wu TH, Chou LH, Chen YR, Huang SF (2013) Comparison of IHC, FISH and RT-PCR methods for detection of 
ALK rearrangements in 312 non-small cell lung cancer patients in Taiwan. PLoS One 8(8):e70839. https://doi.org/10.1371/journal. pone. 0070839

79. Beadling C, Wald AI, Warrick A, Neff TL, Zhong S, Nikiforov YE, Corless CL, Nikiforova MN (2016) A multiplexed amplicon approach for detecting gene fusions by Next-generation sequencing. J Mol Diagn 18(2):165-175. https://doi.org/10.1016/j.jmoldx. 2015.10.002

80. Fehr A, Loning T, Stenman G (2011) Mammary analogue secretory carcinoma of the salivary glands with ETV6-NTRK3 gene fusion. Am J Surg Pathol 35(10):1600-1602. https://doi.org/10.1097/PAS. 0b013e31822832c7

81. Gatalica Z, Xiu J, Swensen J, Vranic S (2018) Molecular characterization of cancers with NTRK gene fusions. Modern pathology : an official journal of the United States and Canadian Academy of Pathology, Inc https://doi.org/10.1038/s41379-018-0118-3

82. Zhang J, White NM, Schmidt HK, Fulton RS, Tomlinson C, Warren WC, Wilson RK, Maher CA (2016) INTEGRATE: gene fusion discovery using whole genome and transcriptome data. Genome Res 26(1):108-118. https://doi.org/10.1101/gr.186114.114

83. Maher CA, Kumar-Sinha C, Cao X, Kalyana-Sundaram S, Han B, Jing X, Sam L, Barrette T, Palanisamy N, Chinnaiyan AM (2009) Transcriptome sequencing to detect gene fusions in cancer. Nature 458(7234):97-101. https://doi.org/10.1038/nature07638

84. Farago AF, Le LP, Zheng Z, Muzikansky A, Drilon A, Patel M, Bauer TM, Liu SV, Ou SH, Jackman D, Costa DB, Multani PS, Li GG, Hornby Z, Chow-Maneval E, Luo D, Lim JE, Iafrate AJ, Shaw AT (2015) Durable clinical response to entrectinib in NTRK1rearranged non-small cell lung cancer. J Thorac Oncol 10(12): 1670-1674. https://doi.org/10.1097/01.JTO.0000473485.38553.f0

85. Alvarez-Breckenridge C, Miller JJ, Nayyar N, Gill CM, Kaneb A, D'Andrea M, Le LP, Lee J, Cheng J, Zheng Z, Butler WE, Multani P, Chow Maneval E, Ha Paek S, Toyota BD, Dias-Santagata D, Santagata S, Romero J, Shaw AT, Farago AF, Yip S, Cahill DP, Batchelor TT, Iafrate AJ, Brastianos PK (2017) Clinical and radiographic response following targeting of BCAN-NTRK1 fusion in glioneuronal tumor. NPJ Precis Oncol 1(1):5. https://doi.org/10. 1038/s41698-017-0009-y

86. Murphy DA, Ely HA, Shoemaker R, Boomer A, Culver BP, Hoskins I, Haimes JD, Walters RD, Fernandez D, Stahl JA, Lee J, Kim KM, Lamoureux J, Christiansen J (2017) Detecting gene rearrangements in patient populations through a 2-step diagnostic test comprised of rapid IHC enrichment followed by sensitive nextgeneration sequencing. Appl Immunohistochem Mol Morphol 25(7):513-523. https://doi.org/10.1097/PAI.0000000000000360

87. Qadir MA, Zhan SH, Kwok B, Bruestle J, Drees B, Popescu OE, Sorensen PH (2014) ChildSeq-RNA. a next-generation sequencingbased diagnostic assay to identify known fusion transcripts in childhood sarcomas J Mol Diagn 16(3):361-370. https://doi.org/10. 1016/j.jmoldx.2014.01.002

88. Chang KTE, Goytain A, Tucker T, Karsan A, Lee CH, Nielsen TO, $\mathrm{Ng}$ TL (2018) Development and evaluation of a pan-sarcoma fusion gene detection assay using the NanoString nCounter platform. J Mol Diagn 20(1):63-77. https://doi.org/10.1016/j.jmoldx.2017.09.007

89. Lindquist KE, Karlsson A, Leveen P, Brunnstrom H, Reutersward C, Holm K, Jonsson M, Annersten K, Rosengren F, Jirstrom K, Kosieradzki J, Ek L, Borg A, Planck M, Jonsson G, Staaf J (2017) Clinical framework for next generation sequencing based analysis of treatment predictive mutations and multiplexed gene fusion detection in non-small cell lung cancer. Oncotarget 8(21): 34796-34810. https://doi.org/10.18632/oncotarget.16276

90. Hyman DM, Solit DB, Arcila ME, Cheng DT, Sabbatini P, Baselga J, Berger MF, Ladanyi M (2015) Precision medicine at memorial Sloan Kettering Cancer center: clinical next-generation sequencing enabling next-generation targeted therapy trials. Drug Discov Today 20(12):1422-1428. https://doi.org/10.1016/j.drudis.2015. 08.005

Publisher's Note Springer Nature remains neutral with regard to jurisdictional claims in published maps and institutional affiliations. 